\title{
The Impact of Local Participation on Community Support for Natural Resource Management: The Case of Mining in Northern Canada and Northern Sweden
}

\author{
Sverker C. Jagers,
}

Professor, Department of Political Science, University of Gothenburg

\section{Simon Matti`,}

Associate Professor, Department of Political Science, Lulea University of Technology

\section{Greg Poelzer,}

Professor, The School of Environment and Sustainability, University of Saskatchewan

\section{Stan Yu}

Research Associate, The International Centre for Northern Governance and Development, University of Saskatchewan

\begin{abstract}
Due to its oftentimes complex, contested, and multi-scale character, natural resource management (NRM) tends to be a challenging task that has been met with various political approaches in order to meet demands for legitimacy. One approach to enhancing the legitimacy of NRM that has gained increased attention within the academic literature is the adoption of local participatory democracy in decision-making processes. Advocates of participatory democracy in NRM propose that local participation achieves the following outcomes: increased legitimacy because it ensures that local needs and priorities are successfully met; decision-making based on more complete information, which helps avoid unexpected negative outcomes; and a sense of belonging and influence among the public, leading to increased perceptions of support and partnership, as opposed to NRM which is imposed on the community. Nevertheless, comprehensive empirical studies that document how public participation affects legitimacy remain rare. Using 2015 data collected on people's attitudes towards mining in northern Saskatchewan, Canada, and Norrbotten and Västerbotten counties, Sweden, this paper empirically assesses whether and how perceptions
\end{abstract}

\footnotetext{
^Correspondence to: Simon.Matti@1tu.se
} 
of local participation affect the legitimacy of mining development. In turn, this paper finds that perceived public participation does affect the public's propensity to support mining development and this propensity is mediated by people's perceptions of the interests present in the decisionmaking process, their normative beliefs concerning which actors should be allowed to participate in the decision-making process, and certain individual-level and contextual-level factors.

Keywords: legitimacy; Natural Resource Management; input legitimacy; output legitimacy; throughput legitimacy; northern communities; local participation; northern canada; northern sweden; mining

Responsible Editor: Hans-Kristian Hernes, UiT - The Arctic University of Norway, Tromsø, Norway.

Received: April 2017; Accepted: April 2018; Published: June 2018

\section{Introduction}

The notion of legitimacy, or "a generalized perception or assumption that the actions of an entity are desirable, proper, or appropriate within some socially constructed system of norms, values, beliefs, and definitions," ${ }^{1}$ holds a position of importance in relation to outcomes of policies related to natural resource management. Without establishing legitimacy, the process of natural resource development can lead to controversies between stakeholders. The existing literature has documented that such controversies most often involve at least three stakeholders: local communities, industry, and government, and typically revolve around issues related to the economic, ${ }^{2}$ social, ${ }^{3}$ cultural, ${ }^{4}$ and environmental impacts ${ }^{5}$ on the community. Controversies where lack of support and acceptance at the community level have led to public outcry and resistance, such as the Trans Mountain oil pipeline in Canada, ${ }^{6}$ and Beowulf Mining's plans to exploit the Kallak iron deposit in Sweden, ${ }^{7}$ have received extensive media coverage.

Due to the complex, contested, and multi-scale nature of natural resource management (NRM), various political approaches have been proposed to meet demands for legitimacy. These have ranged from scaling-down political decision-making to sub-local levels and widening participation in these processes to include local stakeholder representatives, to placing legal demands on extractive industries to facilitate public participation in various ways.

The latter approach has gained increasing attention amongst decision-makers, as well as political science and public administration scholars. Advocates of this approach purport that the inclusiveness and transparency of increased public participation has great potential to improve the legitimacy of political decisions. Specifically, deepened public involvement is generally perceived as being more normatively legitimate due to the enhancement of procedural fairness and democratic values, and the empowerment of marginalized groups. ${ }^{8}$ It can also create a sense of shared loyalty and commitment to decision-making outputs. ${ }^{9}$ In practice, public participation in NRM has 
manifested in many different forms, such public consultation, advisory committees, town hall meetings, local benefit agreements, or citizens' juries. ${ }^{10}$

However, although increasing public participation in decision-making processes is increasingly popular as a means of increasing the legitimacy of both political processes and decisions, comprehensive empirical studies that attempt to disentangle the mechanisms through which participation gives rise to legitimacy, remain quite rare. ${ }^{11}$ Although looking at actual participation by single individuals in the decisionmaking process is certainly one way of capturing the legitimacy-creating mechanisms, another aspect is to focus on the perceived distance between involved actors and decision-makers, i.e., the level at which decisions are made. It is reasonable to assume that for people who perceive that decisions are made above their heads, support for and the legitimacy of the decisions are lower than in cases where it is perceived that the relative distance between decision-makers and the public is smaller. This paper contributes to these attempts by asking whether and how perceived participation defined as the involvement of local-level actors in the process - affects legitimacy on the output-side. Specifically, we explore three research questions:

1. Do perceptions of where decision-making power lies affect people's propensity to support policy decisions?

2. If a relationship between people's perceived participation and support for policy decisions exists, is this relationship mediated by people's preferences for participation, i.e. which actors and interests are present and/or ought to be in the decision-making process?

3. Do any individual-level (e.g. gender, age, income, education, and occupation) and contextual-level factors (e.g. the formal rules and regulations governing NRM, as well as the design of the political-administrative system) influence people's propensity to support policy decisions?

We explore these research questions through an analysis of original survey-data comprising a random sample of citizens living in two mining municipalities in the Canadian province of Saskatchewan, and in three mining municipalities in the northern part of Sweden. Thus, our analysis allows for a cross-country comparison, as the two data sets include necessary variation in institutional context: While both countries are located in the far North, are rich in natural resources and have large-scale mining activities development, they differ significantly in terms of institutional context: the Canadian province Saskatchewan is part of a federal political system, while Norrbotten county in Sweden is part of a unitary state system. In addition, the rules and regulations governing mine exploration and development, including access of local communities to the decision-making processes, clearly separates the two regions. ${ }^{12}$

Moreover, mining offers an interesting empirical case to study when it comes to natural resource management and legitimacy, since it is typically associated with conflicting interests and goals. On the one hand, the establishment of a mine can 
generate employment and contribute to infrastructure, not least in small and remote communities that live constantly under the risk of population decline. On the other hand, mining exploitation often interferes with environmental interests and the cultural and religious values shared by different minority and indigenous groups. Thus, decisions to permit mining activities are a good case if we wish to investigate the interaction between perceived participation/power locality and policy support.

The rest of the paper is organized in the following way: In section 2 we review the literature and discuss the concept of participation and how it is related to legitimacy, understood as policy support. In section 3, we briefly present the two cases and account for why our selection of cases is adequate for our objectives. Thereafter we present our methodological approach and the findings from our study. Finally, we discuss the implications of our findings, offer recommendations for further research in this area, and provide some concluding thoughts.

\section{Previous research and theory}

The concepts of public- and stakeholder participation are sometimes used interchangeably. Whereas stakeholder participation can be understood as a process where individuals, groups or organizations take an active role in making decisions that affect them, ${ }^{13}$ public participation is a far broader concept and is the practice of involving members of the public in the agenda-setting, decision-making, and policy-forming activities of organizations or institutions responsible for policy development. ${ }^{14}$ A more limited definition of public participation focuses on the perceived distance between the actors involved and decision-makers. One dimension of this is to determine perceptions of the level at which important decisions are actually made. ${ }^{15}$ This latter understanding is the definition that we use in this paper, as it seems relevant for the current demands placed on participatory-NRM in general, and mining practices in particular.

Within each unique mining development, Lucas ${ }^{16}$ outlines that there is a range of public actors potentially entitled to participate in the decision-making process as they are directly affected. These actors include: landowners and occupiers, local residents, the municipal government, and the provincial/county government. In Canada, First Nations members and their governing organizations hold constitutional participatory rights and thus, any natural resource development is subject to the Duty to Consult doctrine. ${ }^{17}$ Additionally, other actors, such as non-governmental organizations, private organizations, academic institutions, and/or quasi-governmental bodies not directly affected, can also have an interest in mining policy and development. ${ }^{18}$

Proposals to increase public participation in the management of natural resources have emerged for various reasons. First, some advocates assert that increased public involvement in decision-making processes can improve input and output legitimacy. Input legitimacy refers to responsiveness to citizens' concerns. ${ }^{19}$ In turn, advocates of participatory democracy propose that decision-making processes, allowing for deepened public involvement, are generally perceived as being more normatively 
legitimate due to the enhancement in procedural fairness and democratic values, and the empowerment of marginalized groups. ${ }^{20}$ Meanwhile, output legitimacy is conceptualized as policies that work effectively, while resonating with citizens' democratic ideals, values, and identity. ${ }^{21}$ For these scholars, deepened public participation in decision-making processes is generally perceived as increasing the level of legitimacy, as personal influence in the procedure, which fosters feelings of control and personal autonomy, is strengthened. ${ }^{22}$

Meanwhile, Reed ${ }^{23}$ introduces pure "pragmatic claims" for stakeholder participation; in other words, participation is a decision-making component that increases the quality and durability of political decisions. Specifically, it has been argued that i) participation safeguards local needs and priorities; ${ }^{24}$ ii) decisions are based on more complete information, which helps avoid unexpected negative outcomes; ${ }^{25}$ and iii) public involvement ensures that interventions and technologies are better adapted to local socio-cultural and environmental conditions. ${ }^{26}$ Given these circumstances, long-term support and active implementation of decisions are enhanced, ${ }^{27}$ which is also said to decrease implementation costs significantly. ${ }^{28}$

A further question that needs to be addressed is why perceived legitimacy matters in decision-making processes. In response, several explanations are plausible. For instance, this can be attributed to the degree to which people think that there are conflicting interests and goals involved in the decision-making process. In other words, if people perceive that there is a joint/shared agreement with regards to a suggested policy aim and its potential benefits, then people are probably less apt to demand participation. Another reason why perceived participation is likely to generate support for a policy position is because people may hold a general normative belief that involved actors ought to have a say or to participate. Thus, when an absence of participation is perceived, it can trigger public resistance against policy proposals.

Nevertheless, there are surprisingly few empirical studies on the outcome qualities of participation. ${ }^{29}$ Whereas a number of studies describe and analyze how participatory processes have been launched and implemented, as well as how these implementations are reflected in public opinion, ${ }^{30}$ there seems to be no consensus regarding its overall benefits. For example, Webler and Tuler ${ }^{31}$ select participants from ten different participatory cases and compare their opinions about the processes within these cases, and the results differ significantly regarding what constitutes a good participatory process. Nevertheless, theoretically, we expect that if people perceive that they are, or have been, adequately involved in pre-decision-making processes, they will be more inclined to comply with and support the decisions once they have been made.

Finally, a number of other factors most likely both reinforce and weaken the potential direct and indirect effects of perceived participation on public support for policy decisions. Based on the existing literature, it is reasonable to assume that individual level factors, such as gender, age, level of education, and indigenous identity, affect one's propensity to support mining projects. ${ }^{32}$ Furthermore, it is quite plausible that contextual factors affect this relationship. Previously, we have articulated some of the 
governance and policy differences related to mining between Canada and Sweden. These differences warrant an investigation into systematic differences between Canadian and Swedish respondents that can be attributed to more contextual factors, such as variation in institutional conditions.

\section{Methodology}

\subsection{Case Studies}

\subsubsection{Norrbotten and Västerbotten counties, Sweden}

The Swedish case comprises data from three municipalities in northern Sweden where mining development is currently ongoing: Jokkmokk and Kiruna municipalities in the county of Norrbotten, as well as Storuman municipality in the county of Västerbotten. Overall, Sweden has a long-standing history of mining and metal refining, stretching back more than a thousand years. Today, Sweden is by far the largest iron ore producer in the EU, and is also among the foremost producers of base and precious metals. In absolute terms, the mining and minerals industry supplies export products with an annual value of just over EUR 17.5 billion. In 2013, the industry's share of Swedish GDP amounted to 1.3 percent, not accounting for the vast indirect economic effects of the mining and minerals industry. ${ }^{33}$

The majority of Swedish mines, as well as current exploration activities, are located in the inland areas of the two northernmost counties: Norrbotten and Västerbotten. Even though the region is sparsely populated ${ }^{34}$, with the majority of the population residing in cities along the eastern coast, proposals for opening new mines in these municipalities must still negotiate conflicts with alternative land uses such as tourism, recreation and claims of sustained nature conservation. Furthermore, the establishment of mining in northern Sweden is severely complicated by conflicts concerning unresolved indigenous land rights. For example, in all three municipalities, the proposed new mines infringe on reindeer herding pastures and grazing areas, thus interfering with the legally protected practice of reindeer husbandry. Simultaneously, the possible positive impact of mine development on local economic development, primarily through an increase in employment opportunities, is stressed as an important positive effect, both from a local and a regional perspective. ${ }^{35}$

The Swedish mining and minerals policy is strongly centralised in a few governmental agencies appointed by the government, in particular the Geological Survey of Sweden (SGU) and its Chief Mining Inspector, which hold responsibility for a range of decisions on exploration and mining-establishment projects. ${ }^{36}$ The regulatory framework that requires companies to inform landowners and other local stakeholders, as well as the Sami parliament before initiating exploration has been strengthened in recent years (e.g. Prop. 2013/14:159). If stakeholders raise concerns against exploration, the mining company has a duty to try and reach agreement. Nevertheless, if no such agreement can be reached, SGU makes the final decision. For gaining exploitation concessions there are no legal requirements for consultation with local 
Sverker C. Fagers et al.

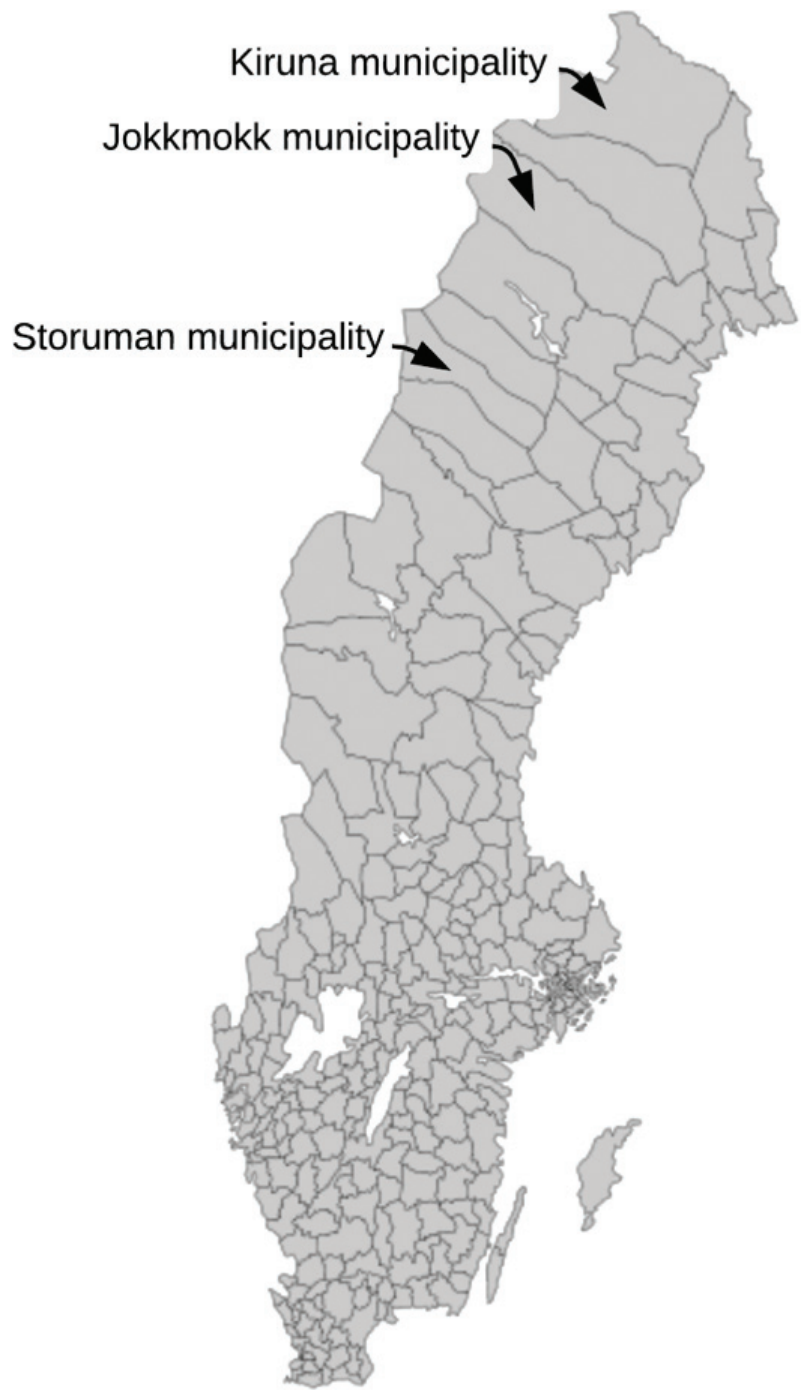

Figure 1. Map of Sweden

actors. ${ }^{37}$ The legal possibilities for local actors, including the municipality, to influence the decision-making process is thereby strictly limited.

\subsubsection{Northern Saskatchewan, Canada}

The natural resource sector is enormously important to Canada's Gross Domestic Product. According to Natural Resources Canada, ${ }^{38}$ in 2015, the natural resource sector comprised 17 per cent of Canada's GDP. The natural resource sector is also considered one of the largest employers of Canadian indigenous peoples, and 


\section{Saskatchewan Northern Administration District}

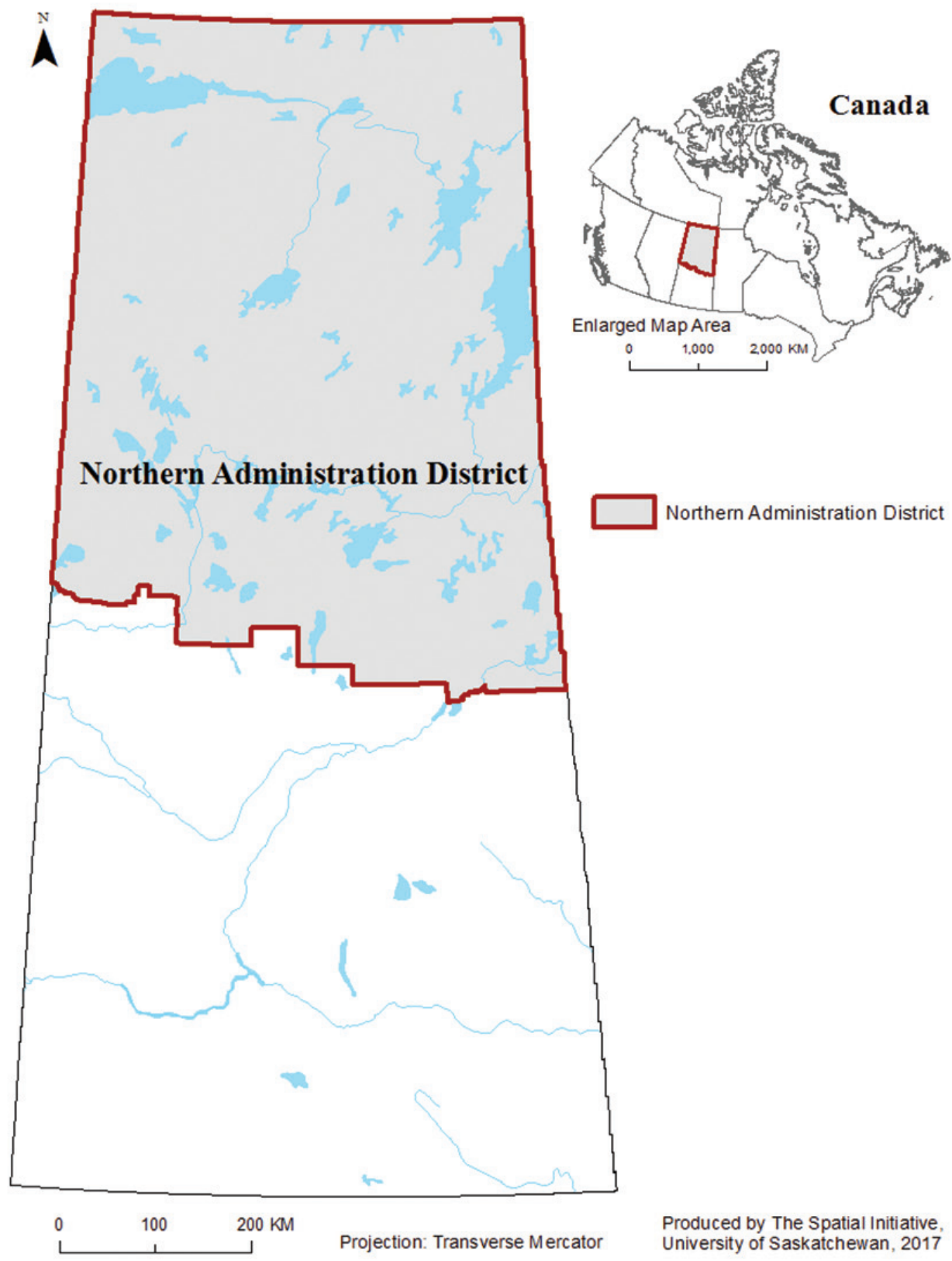

Figure 2. Map of Canada 
provides high paying and stable employment in many remote parts of the country, even for those with little formal education. ${ }^{39}$ Saskatchewan offers an optimal example of the importance of the natural resources sector on the regional development of northern and remote regions.

The Northern Administration District of Saskatchewan (NAD), which lies in the northern half of the central Canadian province, accounts for all of Canada's and about 17 per cent of the world's uranium production. ${ }^{40}$ This makes northern Saskatchewan the second largest uranium-producing region in the world. The two largest uranium companies operating in the NAD are Cameco and Areva, the workforces of which are 50 per cent local and/or indigenous. ${ }^{41}$ The NAD has a population of just under 40,000 individuals and is characterized by northern climates, political marginalization, large indigenous populations, a substantial dependence on resource economies, and arctic and sub-arctic landscapes. ${ }^{42}$

Prince Albert (PA) is the most populated city (approximately 41,000 people) and the closest center for goods and services in northern Saskatchewan. While PA itself is not located close to the mines, the city is home to many value-added services to the resource development companies in the NAD. Moreover, many individuals from the NAD visit PA regularly for goods and services; and countless individuals from the NAD have moved to PA for employment. Thus, PA is intimately tied to the regional development and cultural fabric of northern Saskatchewan.

In Saskatchewan, the Ministry of the Environment, a provincial government department, oversees and makes the final decisions regarding exploration ${ }^{43}$, environmental assessments ${ }^{44}$, and mining permits ${ }^{45}$, with a single exception - uranium mining - which is overseen by the Canadian Nuclear Safety Commission (CNSC) ${ }^{46}$ a federal government agency. Other federal and provincial agencies become involved in the decision making process when an action related to a mining project falls under their jurisdiction - for example obtaining a Mineral Surface Lease Agreement. ${ }^{47}$ Often, large mining projects will trigger an environmental impact assessment (EIA) under the Canadian Environmental Assessment Act at which point the Canadian Environmental Assessment Agency or the CNSC, both federal agencies, coordinates with the Environmental Assessment Branch, a provincial agency, and to administer an EIA. ${ }^{48}$ The EIA is the point in the decision-making process that offers the most opportunities for stakeholders, such as local residents, municipal governments, NGOs, First Nations, provincial and federal agencies to influence the outcome of a project. ${ }^{49}$ During exploration stages, before the EIA process is triggered, provincial best management practices and regulations require industry to engage with First Nations and Métis communities impacted by a project; industry must obtain consent and compensate any private landowners with surface rights. ${ }^{50}$ At any point during the decision-making process, indigenous groups can make a legal challenge regarding the Crown's duty to consult and accommodate. Meanwhile, there are few legal possibilities for non-indigenous actors whose land rights are not impacted, such as municipalities. Indigenous stakeholders are engaged earlier in the mining cycle 
because the bar for triggering the duty to consult and accommodate is lower than for federal or provincial EIAs.

\subsection{Sample and Data}

The Swedish data was collected through a mail survey to a representative sample of about 5,300 persons between the ages of 18-75, living in the three municipalities of Jokkmokk, Kiruna and Storuman, all located in northern Sweden. The sample was provided by Statens personadressregister (SPAR), which is a daily updated public register upheld by the Swedish Tax Agency of all persons who are registered as resident in Sweden with data from the Swedish Population Register. The survey was designed and conducted in line with the ethical guidelines established by the Swedish Research Council. Overall response rate was 32 per cent, which is reasonable for a mail survey of this magnitude. The sample is not perfectly representative of the population as it is somewhat older and more highly educated than the average for these municipalities. In all regressions, we therefore controlled for both age and education, along with several other socio-demographic factors.

In Canada, the survey instrument was translated into English and adapted to the Canadian context by the research team. The University of Saskatchewan's Social Sciences Research Laboratories (SSRL) conducted the survey on behalf of the research team. Using WinCATI software, telephone surveys were administered from December 1, 2015 to December 14, 2015. The survey resulted in 755 completed interviews among randomly-selected residents 18 years of age or older, half of whom were from the Northern Administration District and the other half from Prince Albert. We received a response rate of 25 per cent for the survey, and the results are generalizable to the population of two locations \pm 5.0 per cent at the 95 percent confidence interval (19 times out of 20). The survey received ethics approval from the University of Saskatchewan Research Ethics Board. The overall demographics of respondents in our dataset, separating Swedish and Canadian respondents, are displayed in Tables 1 and 2 .

For respondents in Norrbotten and Västerbotten counties, 52 per cent were male and 48 per cent female. 17 per cent of respondents identified themselves as Sami peoples. When asked about respondents' level of education, we found that 14 per cent of respondents had attained a primary education as their highest level

Table 1. Demographic information for Norrbotten and Västerbotten counties

\begin{tabular}{|c|c|c|c|c|c|c|c|}
\hline \multicolumn{2}{|c|}{ Sex } & \multicolumn{2}{|c|}{ Indigenous status } & \multicolumn{2}{|c|}{ Level of Education } & \multicolumn{2}{|c|}{ Age } \\
\hline Male & $52 \%$ & Indigenous (Sami) & $17 \%$ & Primary education & $14 \%$ & Median & 55 \\
\hline \multirow[t]{2}{*}{ Female } & $48 \%$ & Non-Indigenous & $83 \%$ & Secondary education & $49 \%$ & & \\
\hline & & & & $\begin{array}{l}\text { Postsecondary education } \\
\text { or above }\end{array}$ & $37 \%$ & & \\
\hline
\end{tabular}


Sverker C. Fagers et al.

Table 2. Demographic information for northern Saskatchewan

\begin{tabular}{|c|c|c|c|c|c|c|c|}
\hline \multicolumn{2}{|c|}{ Sex } & \multicolumn{2}{|c|}{ Indigenous status } & \multicolumn{2}{|c|}{ Level of Education } & \multicolumn{2}{|c|}{ Age } \\
\hline Male & $52 \%$ & $\begin{array}{l}\text { Indigenous (First } \\
\text { Nations, Metis) }\end{array}$ & $40 \%$ & Primary education & $5 \%$ & Median & 55 \\
\hline \multirow[t]{2}{*}{ Female } & $48 \%$ & Non-Indigenous & $60 \%$ & Secondary education & $34 \%$ & & \\
\hline & & & & $\begin{array}{l}\text { Postsecondary education } \\
\text { or above }\end{array}$ & $61 \%$ & & \\
\hline
\end{tabular}

of education, 49 per cent had attained a secondary education, and 37 per cent had attained a postsecondary education or above. The median age of the respondents was 55 years of age. Meanwhile, respondents in northern Saskatchewan comprised 52 per cent male and 48 per cent female. 40 per cent of respondents identified themselves to be First Nations or Metis, i.e. with indigenous status in Canada, while 60 per cent of respondents identified as non-indigenous. 5 per cent of respondents had attained a primary education as their highest level of education, 34 per cent had attained a secondary education, and 61 per cent had attained a postsecondary education or above. Finally, the median age of the respondents in northern Saskatchewan was 55 years of age.

\section{Findings}

\subsection{Descriptive statistics}

Table 3 presents the summary statistics for the items on attitudes towards decisionmaking, i.e. the respondents' preferences for decision-making level as well as for participation by stakeholders and local communities. Overall, respondents were found to most likely agree that local interests should be given more say in the mining development process (mean $=5.34$ ) and that decisions regarding mining development should be made by the community (mean $=5.00$ ). The mean for agreement then drops as the proposed decision-making processes moves up to the regional and national level. When asked, respondents further agreed slightly that indigenous peoples' interests should be given more say in the mining development process (mean $=4.21)$. When asked about what decision-making role should be played by the provincial/county and national government, respondents agreed slightly that the provincial/county government should make decisions regarding mining development (mean $=4.31$ ), while they disagreed slightly that the national government should play a role (mean $=3.77)$. In Table 3 , two additional items garnered a higher level of disagreement from the respondents. First, 45.3 per cent of respondents disagreed, in comparison to 38.6 per cent who agreed, that local municipalities should be able to stop mining development permanently (mean $=3.85$ ). Similarly, the majority of respondents (56.3 per cent) disagreed that affected indigenous communities should 
Table 3. Summary Statistics on Decision-Making Items

\begin{tabular}{|c|c|c|}
\hline \multirow[t]{2}{*}{ Decisions regarding mining development should be made by the community } & $\begin{array}{l}\text { Mean } \\
(\text { S.D. })\end{array}$ & $\begin{array}{c}5.00 \\
(1.82)\end{array}$ \\
\hline & $\mathrm{n}$ & 2371 \\
\hline \multirow[t]{2}{*}{ Decisions regarding mining development should be made by the Province/County } & $\begin{array}{l}\text { Mean } \\
\text { (S.D.) }\end{array}$ & $\begin{array}{c}4.31 \\
(1.87)\end{array}$ \\
\hline & $\mathrm{n}$ & 2346 \\
\hline \multirow[t]{2}{*}{$\begin{array}{l}\text { Decisions regarding the mining development should be made by the National } \\
\text { Government }\end{array}$} & $\begin{array}{l}\text { Mean } \\
\text { (S.D.) }\end{array}$ & $\begin{array}{l}3.77 \\
(1.99)\end{array}$ \\
\hline & $\mathrm{n}$ & 2347 \\
\hline \multirow[t]{2}{*}{ Local interests should be given more say in the mining development process } & $\begin{array}{l}\text { Mean } \\
\text { (S.D.) }\end{array}$ & $\begin{array}{l}5.34 \\
(1.66)\end{array}$ \\
\hline & $\mathrm{n}$ & 2370 \\
\hline \multirow[t]{2}{*}{$\begin{array}{l}\text { Indigenous peoples' interests should be given more say in the mining development } \\
\text { process }\end{array}$} & $\begin{array}{l}\text { Mean } \\
\text { (S.D.) }\end{array}$ & $\begin{array}{c}4.21 \\
(2.19)\end{array}$ \\
\hline & $\mathrm{n}$ & 2366 \\
\hline \multirow[t]{2}{*}{ Local municipalities should be able to stop mining development permanently } & $\begin{array}{l}\text { Mean } \\
\text { (S.D.) }\end{array}$ & $\begin{array}{l}3.85 \\
(2.20)\end{array}$ \\
\hline & $\mathrm{n}$ & 2361 \\
\hline \multirow[t]{2}{*}{$\begin{array}{l}\text { Affected Indigenous communities should be able to stop mining development } \\
\text { permanently }\end{array}$} & $\begin{array}{l}\text { Mean } \\
(\text { S.D. })\end{array}$ & $\begin{array}{c}3.39 \\
(2.29)\end{array}$ \\
\hline & $\mathrm{n}$ & 2370 \\
\hline
\end{tabular}

Items were asked on a seven-point Likert Scale, ranging from 1 to 7 , where $1=$ strongly disagree and $7=$ strongly agree

be able to stop mining permanently; however, 33.2 per cent agreed with the sentiment (mean $=3.39)$.

In Table 4, summary statistics for our main dependent variable (attitudes towards mining and mining development) is displayed along with one item tapping descriptive social norms and one item focusing on the trade-offs between resource-extraction and environmental protection. Overall, the majority of respondents were generally in favour of mining development, attaining a mean of 4.56. The majority of respondents further agreed that people in their community are generally in favour of mining development (mean $=4.75)$. Most respondents agreed that long-term environmental goals should always be given higher priority than short-term interests in mining development $($ mean $=4.94)$.

To assess the respondents' perceptions of who actually is involved in decision-making processes, we asked them to rate the level of influence of different actors and actor-groups. According to Table 5, respondents were most likely to perceive the mining industry $($ mean $=3.52)$ and the provincial/county government $($ mean $=3.34)$ as having some influence on mining development. Respondents further perceived external organizations and activists outside the North and band governments/sameby as having some influence on mining development. For respondents, the municipality and local environmental organizations have little to some influence on mining 
Sverker C. Fagers et al.

Table 4. Summary Statistics on Mining Attitudes

\begin{tabular}{|c|c|c|}
\hline \multirow[t]{2}{*}{$\begin{array}{l}\text { Long-term environmental goals should always be given higher priority than } \\
\text { short-term interests in mining development. }\end{array}$} & $\begin{array}{l}\text { Mean } \\
\text { (S.D.) }\end{array}$ & $\begin{array}{c}4.94 \\
(1.88)\end{array}$ \\
\hline & $\mathrm{n}$ & 2374 \\
\hline \multirow[t]{2}{*}{ In general, people in your community are in favour of mining development. } & $\begin{array}{l}\text { Mean } \\
\text { (S.D.) }\end{array}$ & $\begin{array}{c}4.75 \\
(1.70)\end{array}$ \\
\hline & $\mathrm{n}$ & 2326 \\
\hline \multirow[t]{2}{*}{ Please rate your general attitudes towards mines and mining development } & $\begin{array}{l}\text { Mean } \\
\text { (S.D.) }\end{array}$ & $\begin{array}{l}4.56 \\
(1.88)\end{array}$ \\
\hline & $\mathrm{n}$ & 2398 \\
\hline
\end{tabular}

Items 1 - 2 were asked on a seven-point Likert Scale, ranging from 1 to 7 , where $1=$ strongly disagree and 7 = strongly agree; item 3 was asked on a seven-point Likert Scale, ranging from 1 to 7 , where $1=$ very negative, $4=$ neither negative nor positive, and $7=$ very positive

Table 5. Summary Statistics on Influence Items

\begin{tabular}{|c|c|c|}
\hline \multirow[t]{2}{*}{ Band Government ${ }^{51} /$ Sameby } & $\begin{array}{l}\text { Mean } \\
\text { (S.D.) }\end{array}$ & $\begin{array}{c}2.75 \\
(0.97)\end{array}$ \\
\hline & $\mathrm{n}$ & 2142 \\
\hline \multirow[t]{2}{*}{ Affected resource users (trappers, fishermen, reindeer herders, etc.) } & $\begin{array}{l}\text { Mean } \\
\text { (S.D.) }\end{array}$ & $\begin{array}{c}2.48 \\
(0.94)\end{array}$ \\
\hline & $\mathrm{n}$ & 2196 \\
\hline \multirow[t]{2}{*}{ Local environmental organizations } & $\begin{array}{l}\text { Mean } \\
\text { (S.D.) }\end{array}$ & $\begin{array}{c}2.55 \\
(0.94)\end{array}$ \\
\hline & $\mathrm{n}$ & 2190 \\
\hline \multirow[t]{2}{*}{ Local businesses } & $\begin{array}{l}\text { Mean } \\
\text { (S.D.) }\end{array}$ & $\begin{array}{c}2.37 \\
(0.90)\end{array}$ \\
\hline & $\mathrm{n}$ & 2207 \\
\hline \multirow[t]{2}{*}{ The municipality } & $\begin{array}{l}\text { Mean } \\
\text { (S.D.) }\end{array}$ & $\begin{array}{c}2.58 \\
(0.98)\end{array}$ \\
\hline & $\mathrm{n}$ & 2179 \\
\hline \multirow[t]{2}{*}{ External organizations and activists (i.e. outside the North) } & $\begin{array}{l}\text { Mean } \\
\text { (S.D.) }\end{array}$ & $\begin{array}{c}2.81 \\
(0.92)\end{array}$ \\
\hline & $\mathrm{n}$ & 2171 \\
\hline \multirow[t]{2}{*}{ The mining industry } & $\begin{array}{l}\text { Mean } \\
\text { (S.D.) }\end{array}$ & $\begin{array}{c}3.52 \\
(0.74)\end{array}$ \\
\hline & $\mathrm{n}$ & 2210 \\
\hline \multirow[t]{2}{*}{ The Provincial/County Government } & $\begin{array}{l}\text { Mean } \\
\text { (S.D.) }\end{array}$ & $\begin{array}{c}3.34 \\
(0.83)\end{array}$ \\
\hline & $\mathrm{n}$ & 2182 \\
\hline
\end{tabular}

Items were asked on a four-point Likert Scale, ranging from 1 to 4 , where $1=$ no influence and $4=$ much influence

development decisions. Of the actors listed, respondents perceived affected resource users and local businesses to have the least amount of influence on mining development in their communities.

To construct our main independent variable, i.e. preferences for increased participation, a principal axis factor analysis with oblique rotation was conducted on the 
seven items (see Table 3 above) related to attitudes on decision-making within the mining development process. This method was selected for its ability to account for correlations between the produced factors. ${ }^{52}$ Only correlations larger than .50 and eigenvalues of about 1 were retained. An analysis of the Kaiser-Meyer Okin measure of sampling adequacy indicated that the sample was suitable (KMO =0.696).

As a result, one factor was generated. This factor encompasses the items related to the opinion that indigenous communities and local interests should be given more input during the mining development process, and even hold the ability to stop mining development permanently. Corresponding to the literature, this factor was labelled as "veto power". The three items asking respondents whether the community, the provincial/county government, or the national government should make decisions regarding mining did not load in the factor analysis.

Utilizing the same methodology, a principal axis factor analysis with oblique rotation was further conducted on the set of items tapping the perceived level of

Table 6. Factor Analysis of Decision-making Variables

\begin{tabular}{lc}
\hline & Factor 1 Veto Power \\
\hline $\begin{array}{l}\text { Affected Indigenous communities should be able to stop mining development } \\
\text { permanently }\end{array}$ & 0.889 \\
$\begin{array}{l}\text { Indigenous peoples' interests should be given more say in the mining development } \\
\text { process }\end{array}$ & 0.804 \\
Local municipalities should be able to stop mining development permanently & 0.779 \\
$\begin{array}{l}\text { Local interests should be given more say in the mining development process } \\
\text { Eigenvalues } \\
\% \text { of variance }\end{array}$ & 0.538 \\
\hline
\end{tabular}

Table 7. Factor Analysis on Perceived Influence on Mining Items

\begin{tabular}{lcc}
\hline & \multicolumn{2}{c}{ Factor } \\
\cline { 2 - 3 } & $\begin{array}{c}\text { 1 Local Actor } \\
\text { Influence }\end{array}$ & $\begin{array}{c}\text { 2 External Actor } \\
\text { Influence }\end{array}$ \\
\hline Local environmental organizations & .784 & \\
Affected resource users (trappers, fishermen, Reindeer Herders, etc.) & .669 & \\
Band Government/ Sameby & .657 & \\
The municipality & .650 & .628 \\
Local businesses & .568 & .565 \\
The mining industry & & .506 \\
The Provincial/County Government & & 1.49 \\
External organizations and activists (i.e. outside the North) & 3.02 & $18.65 \%$ \\
Eigenvalues & $37.76 \%$ & \\
\% of variance & & \\
\hline
\end{tabular}


influence certain actors had on the mining decision-making process. An analysis of the Kaiser-Meyer Okin measure of sampling adequacy indicated that the sample was suitable $(\mathrm{KMO}=0.786)$. All eight survey-items loaded into the factor analysis. In turn, two factors were produced based on locality. The first factor clusters five items based on the perceived level of influence from five actors, including local environmental organizations, affected resource users, the local indigenous government, municipality, and local businesses. This can be encapsulated as "perceived local actor influence". Meanwhile, the second factor consists of three items based on the perceived level of influence from three actors, including the mining industry, the provincial/county government, and external organizations and activists outside the North. While it can be argued that these actors are not exclusively external, they are often at least one degree removed from a local community. Thus, we named this factor "perceived external actor influence".

\subsection{Econometric results}

Unweighted summated index scores were generated for three factors produced by the Factor Analysis. Averaged scores were then produced to retain the scale metric and the ability to foster comparisons across factors, as the factors produced differing numbers of items per factor. ${ }^{53}$ We then inserted the three factors and the other survey items on decision-making into regression models, in an effort to determine whether these variables held predictive effects on the respondents' general attitudes towards mining. To further test the predictive effects of the aforementioned variables, we produced a second model where we added demographic variables to assess their predictive effects in comparison to the decision-making variables-only model. We further added a location variable to assess whether being located in northern Saskatchewan vis-à-vis Norrbotten and Västerbotten counties has an impact on attitudes towards mining.

Table 8 presents the findings of the regression analyses for all respondents. To empirically explore the conceptual research questions in this study, hierarchical regression was utilized, which assesses the amount of variance explained by our independent variables, relative to each other and the demographic control variables. This is represented in Models A - D.

First, Model A contains only the effects of the demographic control variables of sex, age, level of education, indigenous identity, and location on respondents' attitudes towards mining. Resultantly, it was found that the variables of sex, level of education, and indigenous identity all exhibit inverse relationships with one's attitudes towards mining. In other words, females, those with a higher level of education, and indigenous respondents are less likely to perceive mining positively in comparison to males; those with a higher level of education are less likely to perceive mining positively; and indigenous respondents are less likely to perceive mining positively in comparison to non-indigenous respondents. In contrast, the Swedish respondents were significantly less likely to perceive mining positively when compared to 
Table 8. OLS Regression Models for All Respondents

\begin{tabular}{lcccc}
\hline & Model A & Model B & Model C & Model D \\
\hline Female & $-0.138^{\star \star \star}$ & $-0.065^{\star \star \star}$ & $-0.080^{\star \star \star}$ & $-0.043^{\star \star}$ \\
Age & $(0.084)$ & $(0.070)$ & $(0.066)$ & $(0.058)$ \\
& -0.010 & -0.022 & -0.027 & -0.012 \\
Level of Education & $(0.003)$ & $(0.002)$ & $(0.002)$ & $(0.002)$ \\
& $-0.122^{\star \star \star}$ & $-0.078^{\star \star \star}$ & -0.031 & -0.013 \\
Indigenous identity & $(0.067)$ & $(0.055)$ & $(0.053)$ & $(0.046)$ \\
& $-0.260^{\star \star \star}$ & $-0.137^{\star \star \star}$ & $-0.108^{\star \star \star}$ & -0.008 \\
Norrbotten and Västerbotten counties & $(0.104)$ & $(0.088)$ & $(0.083)$ & $(0.076)$ \\
& $-0.234^{\star \star \star}$ & -0.005 & 0.009 & $-0.060^{\star \star}$ \\
Long-term environmental goals should always & $(0.101)$ & $(0.089)$ & $(0.085)$ & $(0.076)$ \\
be given priority than short-term interests in & & $0.353^{\star \star \star}$ & $0.257^{\star \star \star}$ & $0.201^{\star \star \star}$ \\
mining development & & $(0.023)$ & $(0.023)$ & $(0.020)$ \\
In general, people in your community are in & & $0.312^{\star \star \star}$ & $0.270^{\star \star \star}$ & $0.218^{\star \star \star}$ \\
favor of mining development & & $(0.025)$ & $(0.024)$ & $(0.021)$ \\
Factor - Perceived Local Actor Influence & & & $0.302^{\star \star \star}$ & $0.166^{\star \star \star}$ \\
& & & $(0.053)$ & $(0.050)$ \\
Factor - Perceived External Actor Influence & & -0.131 & $-0.043^{\star}$ \\
Factor - Veto Power & & & $(0.059)$ & $(0.054)$ \\
Constant & & & & $-0.422^{\star \star \star}$ \\
$\mathrm{R}^{2}$ (adj.) & & & & $(0.020)$ \\
$\mathrm{n}$ & & & & \\
& & & & \\
\hline
\end{tabular}

${ }^{\star \star \star} \mathrm{p}<.001,{ }^{\star \star} \mathrm{p}<0.01,{ }^{\star} \mathrm{p}<0.05$

respondents from our Canadian sample (i.e. the negative sign of the coefficient for Norrbotten and Västerbotten counties). Meanwhile, age was not found to have an effect on one's attitudes towards mining. However, while some demographic variables included in our study do significantly predict our sample's attitudes towards mining, they only help to explain 11.8 per cent of the variance.

Model B presents the model with the addition of the items on environmental attitudes and social norms. It was found that both variables displayed a significant and positive relationship with the dependent variable. In other words, respondents who were more likely to agree that long-term environmental goals should always be given priority over short-term interests in mining development and that people in their community are generally in favour of mining were significantly more likely to perceive mining as positive. In Model B, the demographic variables of sex, level of education, and indigenous identity also significantly predicted one's attitudes towards mining. However, in Model B, one's location no longer remains significant. Overall, Model B is statistically significant at the 0.001 level and helps to explain 40.6 per cent of the variance, which is a 28.8 percentage point increase over Model A. 
Following, Model C inserts the variables of Local Actor Influence and External Actor Influence factors, which emerged from the factor analyses. As a result, it was found that respondents who were more likely to perceive local actors as having influence on the decision-making process on mines and mining development were also significantly more likely to have a positive attitude towards mining. However, no significant effects on mining attitudes were observed for perceptions of external actor influence. In Model C, the items on environmental attitudes and social norms also significantly predict the dependent variable, as do the demographic variables of sex and indigenous identity. Meanwhile, one's level of education no longer predicts one's attitudes towards mining. Overall, Model C significantly predicts the dependent variable and explains 47.5 per cent of the variance, which is approximately a 7 percentage point improvement.

Finally, Model D adds the variable of Veto Power, which emerged from the factor analyses. As a result, it was found that Veto Power has an inverse relationship with the dependent variable. In other words, respondents who were more likely to agree that local communities and indigenous communities should hold veto power over mines and mining development were also less likely to perceive mining as positive. The effect of Veto Power was found to be statistically significant at the 0.001 level of significance. Moreover, in Model D, the variables of perceived Local Actor Influence, and the items on environmental attitudes and social norms continue to significantly predict the dependent variable. In this model, perceived External Actor Influence becomes a significant predictor of one's attitudes towards mining. One's location also impacts attitudes towards mining. Specifically, respondents from Norrbotten and Västerbotten counties are less likely to view mining as positive compared to respondents in Northern Saskatchewan. Similar to Models A - C, males were significantly more likely to perceive mining and mining development positively compared to females. On the other hand, age, level of education, and indigenous identity do not significantly predict the dependent variable. Model D demonstrates the strongest model of the four, helping to explain 59.1 per cent of the variance, which is an 11.6 percentage point increase over Model C, and a 47.3 percentage point increase compared to the base-model with only demographic variables included.

\section{Discussion}

This study set forth to empirically study whether and how perceptions of the involvement of local-level actors in the decision-making process affects legitimacy on the output-side in the form of support for natural resource management in the mining sector. In turn, our findings suggest that individual perceptions of where decisionmaking power lies in the decision-making process for mining development, do affect one's propensity to support mining development. Furthermore, our findings suggest one's level of acceptance towards mining development is mediated by people's perceptions of the interests present in the decision-making process, their normative 
beliefs concerning which actors ought to be allowed to participate in the decisionmaking process, and certain individual-level and contextual-level factors.

Specifically, as illustrated by Model D in Table 8, it was revealed that people who perceived local actors as having influence on the decision-making process in mining development were significantly more likely to perceive mining development as positive. In contrast, people who were more likely to perceive external actors as having influence on the decision-making process in mining development were significantly less likely to perceive mining development as positive. These findings offer some empirical support to the notion that the perceived location of or level of power in the decision-making process does affect people's propensity to support policy decisions. Moreover, this finding suggests that the perception of who participates in the decision-making process is especially important in relation to certain actors. In particular, we see that one's propensity to support mining development tends to increase when local voices are heard and incorporated into decision-making, while one's propensity to support mining development significantly decreases when external voices are perceived to have more influence on policy. This finding suggests that throughput legitimacy, or "quality of governance processes as established by their efficacy, accountability, transparency, inclusiveness, and openness to interest intermediation" ${ }^{54}$ can lead to output legitimacy. In other words, where processes are in place for local communities to feel included and empowered to contribute to decision-making, there is likely to be increased public support for mining. However, this support will certainly be conditioned by the extent to which local actors are responsive to and act on the preferences of the local community.

In terms of people's normative beliefs pertaining to who ought to be allowed to participate, our findings reveal that those who believe that local and indigenous interests should have more say over mining development, or have the ability to stop mining development, were significantly less likely to support mining development. This finding further supports the importance of throughput legitimacy in decision-making processes within the mining sector. In particular, we suggest that respondents who perceive a lack of efficacy and inclusion in the decision-making process are more likely to cultivate a position of opposition towards mining. As revealed by the findings in this study, respondents who do not perceive local and indigenous interests as having an influence over mining decisions were less likely to support mining development; whereas, those who perceived local interests as having an influence on decision-making processes related to mining were more likely to support mining. We propose that increasing investment in the local democratization of decision-making will produce an avenue for local communities to increase their sense of efficacy, which in turn, can increase their support for mining development.

However, while the findings in this study suggest that citizens covet local community participation in the decision-making process in relation to mining development, they further indicate that there appears to be a disconnect between citizens' perceived ideal decision-making process and their perception of the actual 
decision-making process. As presented in Tables 3 and 5, while citizens were most likely to agree that local interests should be given more say in the mining development process and that decisions regarding mining development should be made by the community, they concurrently perceive the mining industry and the provincial/ county government as having the most influence in the decision-making process, while local actors were perceived as having the least amount of influence. Again, this disconnect between preferences and reality suggests that the representation of interests in the mining process, in particular in Sweden where decision-making is strongly centralized in national governmental agencies, serves as to delegitimize policy outputs.

In line with previous research, our findings further reveal that social norms were strong predictors of people's propensity to support mining. Interestingly, this study found a significant and positive relationship between people's environmental attitudes and their attitudes towards mining development. In other words, those who were more likely to agree that long-term environmental goals should always be given a higher priority than short-term interests were also more likely to perceive mines and mining development positively. This finding appears to contradict commonly held understandings of this relationship, which argue that these two viewpoints are inconsistent with one another. We hypothesize that this finding could be attributed to the context surrounding northern communities with a history of mining. In these communities, citizens are likely to perceive both environmental goals and the need for mining as important. Particularly, respondents feel that long-term environmental goals should be a priority, but concurrently retain the belief that mining development should continue. Another interesting finding that emerged from this study is that demographic variables are weak predictors in the full regression model, when attitudes and perceptions are included. Here, it is found that only sex and geographical location are predictive of people's attitudes towards mining, while age and level of education, do not impact attitudes towards mining at all. The rather strong negative effect of indigenous identity noted initially also disappears when attitudes and perceptions are included in the model. This finding challenges common perpetuated narratives that indigenous peoples, younger individuals, and those with higher levels of education are primarily against mining and serves to highlight the strength of throughput legitimacy for general attitudes towards mining.

Lastly, although only tested as a dummy variable, our results suggest that context matters in the sense that Swedes appear to display more negative attitudes than Canadians. In part, given the strong effects of the veto-power variable, this might be explained by various differences in formal institutions between the two countries. For instance, constitutional mechanisms, such as indigenous land rights and local self-government, are much stronger in Canada and less so in Sweden. Sámi in Sweden have a legally recognized usufruct right (urminnes hävd), which is compromised by a lack of practical recognition when it comes to third party intrusions (e.g. mining). ${ }^{55}$ Overall, based on a comparison of their respective institutions and governance 
policies, this finding may suggest that respondents in Norrbotten and Västerbotten counties perceive a lower sense of efficacy, contributing to mining being a more controversial issue in Sweden than in northern Saskatchewan. While the findings in this study suggest that differences between the two locations exist and can be attributed to differences in policies and governance, a more thorough analysis in future research is needed.

\section{Conclusion}

The findings of this study offer some evidence that people's perceptions and attitudes are related to their propensity to support mining. The findings contribute to the existing literature by revealing that perceived public participation, in particular the extent to which the public perceive that local and external actors have influence over decision-making processes in mining, and public perceptions regarding which actors ought to have an influence on decision-making processes, affects people's opinions about mining development. Our findings suggest that one's propensity to support mining development increases if local interests are perceived to be represented and have an influence on decision-making processes. This ideal, however, does not appear to reflect current practices, according to our survey results. Thus, we recommend that industry and government invest in the local democratization of decision-making processes in the mining sector. As opposed to any fears that increased democratization at the local level will lead to increased public controversies or vetoes, our study rather suggests that increased democratization at the local level could lead to increased community support for mining development.

This study does have limitations. First, the sample frame was limited to five sites in three regions of two countries. Our understanding of people's attitudes towards mining would benefit from surveying respondents from other regions within the same country. For instance, in Canada, certain eastern provinces are far removed from the energy sector; thus, it is likely that people living in these areas would view mining differently than in Saskatchewan. Replicating this survey in other countries would further provide a more diverse sample and increase the generalizability of our findings. In addition, our study attained an overall response rate of 32 per cent. While this is consistent with large surveys in the literature, external validity would be improved with a larger response rate. Finally, this study specifically focused on a specific sector within natural resource management, i.e. mining. It is quite plausible that the same factors that emerge here may not contribute to the propensity to support other sectors of natural resource management. Lastly, it should be noted that issues surrounding land-use and NRM are usually politically complex and highly contested, involving a range of incompatible interests and actors. This especially obtains for cases in which the historically established and culturally important practices of indigenous communities clash with the industrial extraction of resources. Although our study suggests that the empowerment of local level actors is a route towards decreasing negative 
sentiments and increasing output legitimacy, other studies show that the possibility of reaching consensus and eradicating conflict altogether through participatory and deliberative design is rather difficult when the initial level of conflict is high.

\section{NOTES}

1. Marc C. Suchman, "Managing Legitimacy: Strategic and Institutional Approaches," Academy of Management Review 20, no. 3 (1995): 574.

2. Emma Gilberthorpe and Glenn Banks, "Development on Whose Terms?: CSR Discourse and Social Realities in Papua New Guinea's Extractive Industries Sector,” Resources Policy 37, no. 2 (2012): 185-93.

3. Michael L. Dougherty, "The Global Gold Mining Industry, Junior Firms, and Civil Society Resistance in Guatemala," Bulletin of Latin American Research 30, no. 4 (2011): 403-18.

4. Glenn Banks, "Little by Little, Inch by Inch: Project Expansion Assessments in the Papua New Guinea Mining Industry,” Resources Policy 38, no. 4 (2013): 688-95.

5. Gilberthorpe and Banks, "Development on Whose Terms?"

6. Kyle Bakx, "Kinder Morgan Braces for Standing Rock-Type Protests," CBC Nerws, November 5, 2016. http://www.cbc.ca/news/business/tmx-kindermorgan-bc-oilpatch-pipeline-standing-rock-1.3836489; CBC News, "Kinder Morgan Protest Draws Huge Crowd in Vancouver," CBC News, November 19, 2016. http://www.cbc.ca/news/canada/british-columbia/kinder-morgan-protests-1.3858817.

7. Karin Beland Lindahl, Anna Zachrisson, Simon Matti, Roine Wiklund, Daniel Fjellborg, Andreas Johansson and Lars Elenius, "Konflikter om Gruvetablering - Lokalsamhällets aktörer och vägar till hållbarhet” (Slutrapport till Länsstyrelsen Norrbotten, Luleå, 2016), 1-107.

8. John S. Dryzek, Discursive Democracy: Politics, Policy, and Political Science. Cambridge: Cambridge University Press, 1990; Adam B. Seligman. The Idea of Civil Society. Princeton: Princeton University Press, 1992.; Jon Elster, Deliberative Democracy. Cambridge: Cambridge University Press, 1998.

9. Mark Lubell, "Do Watershed Partnerships Enhance Beliefs Conducive to Collective Action?," In Swimming Upstream: Collaborative Approaches to Watershed Management, eds. Paul Sabatier et al. (Cambridge: MIT Press, 2005), 201-232.; Julia Black, "Constructing and contesting legitimacy and accountability in polycentric regulatory regimes," Regulation E Governance 2, no. 2 (2008): 137-164.; Marc J. Stern, "Coercion, Voluntary Compliance, and Protest: The Role of Trust and Legitimacy in Combating Local Opposition to Protected Areas," Environmental Conservation 35, no. 3 (2008): 200210; Elinor Ostrom, Governing the Commons: The Evolution of Institutions for Collective Action. Cambridge: Cambridge University Press, 1990.; Elinor Ostrom, Understanding Institutional Diversity. Princeton: Princeton University Press, 2005.; Carl Rova, "Flipping the Pyramid. Lessons from Converting Topdown Management of Bleak-roe Fishing” (doctoral thesis, Division of Political Science, Luleå University of Technology, 2004).; Svein Jentoft, "Legitimacy and Disappointment in Fisheries Management," Marine Policy 24, no. 2 (1999): 141-148.; Geir Hønneland, "The Stories Fishermen Tell: Themes from the Barents Sea Fisheries," Human Ecology 27, no. 4 (1999): 621-626.

10. Barry Barton, "Underlying Concepts and Theoretical Issues in Public Participation in Resources Development," In Human Rights in Natural Resource Development: Public Participation in the Sustainable Development of Mining and Energy Resources, eds. Donald N. Zillman, Alastair R. Lucas and George Pring (Oxford: Oxford University Press, 2002), 80.

11. However, see Michael X. Delli Carpini, Fay Lomax Cook and Lawrence R. Jacobs, "Public Deliberation, Discursive Participation, and Citizen Engagement: A Review of the Empirical Literature," Annual Review of Political Science 7, no. 1 (2004): 315-344.; Lubell, Do Watershed Partnerships Enhance Beliefs Conducive to Collective Action?; Anna Karin Elise Zachrisson, "Deliberative Democracy and Co-Management of Natural Resources: Snowmobile Regulation in Western Sweden," International Fournal of the Commons 4, no. 1 (2010): 273-292.; and Heli Saarikoski, Kaisa Raitio and Janice Barry, "Understanding 'Successful' Conflict Resolution: Policy Regime Changes and New Interactive Arenas in the Great Bear Rainforest," Land Use Policy 32 (2013): 271-280. for some prominent exceptions.

12. Lindahl et al., "Konflikter om Gruvetablering - Lokalsamhällets aktörer och vägar till hållbarhet".; Alastair R. Lucas, "Canadian Participatory Rights in Mining and Energy Resource Development: The Bridges 


\section{The Impact of Local Participation on Community Support for Natural Resource Management}

to Empowerment?," In Human Rights in Natural Resource Development: Public Participation in the Sustainable Development of Mining and Energy Resources, eds. Donald N. Zillman, Alastair R. Lucas and George Pring (Oxford: Oxford University Press, 2002), 305-353.

13. Abraham Wandersman, "A Framework of Participation in Community Organizations," fournal of Applied Behavioural Science 17, no. 1 (1981): 27-58.; Gene Rowe and Lynn J. Frewer, "Public Participation Methods: A Framework for Evaluation," Science, Technology \& Human Values 25, no. 1 (2000): 3-29.; Gene Rowe, Roy Marsh and Lynn J. Frewer, "Evaluation of a Deliberative Conference," Science, Technology \& Human Values 29, no. 1 (2004): 88-121.; Mark S. Reed, "Stakeholder Participation for Environmental Management: a Literature Review," Biological Conservation 141, no. 10 (2008): 2417-2431.

14. Vincent Luyet, Rodolphe Schlaepfer, Marc B. Parlange and Alexandre Buttler, "A Framework to Implement Stakeholder Participation in Environmental Projects," Fournal of Environmental Management 11 , no. 1 (2012): 213-219.

15. Ibid.

16. Lucas, Canadian Participatory Rights in Mining and Energy Resource Development.

17. Indian and Northern Affairs Canada, "Government of Canada and the Duty to Consult." Indigenous and Northern Affairs Canada, 2016, https://www.aadnc-aandc.gc.ca/eng/1331832510888/1331832636303.; Lucas, Canadian Participatory Rights in Mining and Energy Resource Development.

18. Lucas, Canadian Participatory Rights in Mining and Energy Resource Development.

19. Fritz W. Scharpf, "Problem-Solving Effectiveness and Democratic Accountability in the EU," Max Planck Institute for the Study of Societies Working Paper 03/1, 2003. http://www.mpifg.de/pu/workpap/ wp03-1/wp03-1.html.

20. Dryzek, Discursive Democracy: Politics, Policy, and Political Science; Seligman. The Idea of Civil Society; Elster, Deliberative Democracy.

21. Mijke Boedeltje and Juul Cornips, "Input and Output Legitimacy in Interactive Governance," NIG Annual Work Conference 2004 Rotterdam, October 19, 2004, https://repub.eur.nl/pub/1750/.

22. Carole Pateman, Participation and Democratic Theory. Cambridge: Cambridge University Press, 1970.; Mark Warren, "Democratic Theory and Self-Transformation," The American Political Science Review 86, no. 1 (1992): 8-23.

23. Reed, Flipping the Pyramid. Lessons from Converting Top-down Management of Bleak-roe Fishing, 2420.

24. Andy Dougill, E.D.G. Fraser, J. Holden, K. Hubacek, C. Prell, M.S. Reed, S. Stagl and L.C. Stringer, "Learning from Doing Participatory Rural Research: Lessons from the Peak District National Park," Fournal of Agricultural Economics 57, no. 2 (2006): 259-275.

25. Thomas C. Beierle, "The Quality of Stakeholder-Based Decisions," Risk Analysis: An International Fournal 22, no. 4 (2002): 739-749.; Jens Newig, "Does Public Participation in Environmental Decisions Lead to Improved Environmental Quality?: Towards an Analytical Framework,” Communication, Cooperation, Participation 1, No. 1 (2007): 51-71.

26. Adrienne M. Martin and John Sherington, "Participatory Research Methods - Implementation, Effectiveness, and Institutional Context," Agricultural Systems 55, No. 2 (1997): 195-216.; Reed, Stakeholder Participation for Environmental Management.

27. Caspian Richards, Kirsty Blackstock and Claudia Carter, "Practical Approaches to Participation," Socio-Economic Research Group Policy Brief 1, 2004, http://www.macaulay.ac.uk/ruralsustainability/ SERG\%20PB1\%20final.pdf.

28. Reed, Stakeholder Participation for Environmental Management.

29. Simon Bell, Stephen Morse and Rupesh A. Shah, "Understanding Stakeholder Participation in Research as Part of Sustainable Development," Journal of Environmental Management 101, no. 1 (2012): 13 22; Marta Conde and Philippe Le Billon, "Why Do Some Communities Resist Mining Projects While Others Do Not?," The Extractive Industries and Society 4, no. 1(2017): 681-697; Jason Prno, "An Analysis of Factors Leading to the Establishment of a Social License to Operate in the Mining Industry," Resources Policy 38, no. 4 (2013): 577-590; Reed, Stakeholder Participation for Environmental Management.

30. Bejerle, The Quality of Stakeholder-Based Decisions.; Rowe, Marsh and Frewer, Evaluation of a Deliberative Conference.

31. Thomas Webler and Seth Tuler, "Four Perspectives on Public Participation Process in Environment Assessment and Decision-Making: Combined Results from Ten Case Studies," Policy Studies fournal 34, No. 4 (2006): 699-722. 


\section{Sverker C. Fagers et al.}

32. Tapio Litmanen, Tuija Jartti and Eero Rantala, "Citizens' Attitudes towards Mining in Finland," FinnishRussian Sustainable Mining Research Seminar, October 2 2016.; Kieran Moffat, Airong Zhang, and Naomi Boughen, “Australian Attitudes toward Mining: Citizen Survey - 2014 Results,” CSIRO Mineral Resources, 2014, http:/www.andev-project.org/wp/wp-content/uploads/2014/09/Australian-AttitudesTowards-Mining-Report.pdf.

33. Swedish Agency for Growth Policy Analysis, "Sverige - ett attraktivt gruvland i världen? En internationell jämförelse [Sweden - an attractive mining country in the world? An international comparison]," (Stockholm: Myndigheten för tillväxtpolitiska utvärderingar och analyser, 2016), 1-38.; SGU - the Geological Survey of Sweden (2016). "Mineral Resources," SGU - Geological Survey of Sweden. Last modified March 12, 2017. https:/www.sgu.se/en/mineral-resources/.; Sweden. Ministry of Industry. Bättre information och tydligare ansvar vid mineralprospektering [Better information and clearer responsibility in mineral prospecting], Prop. (2013/14:159). Stockholm: Swedish Parliamentary Offices.

34. About 515000 of Sweden's 10 million inhabitants reside in Norrbotten and Västerbotten, which occupies about a third, or $150000 \mathrm{~km}^{2}$, of Sweden's total area. The municipality of Jokkmokk has about 5000 inhabitants, Storuman about 6000 and Kiruna, geographically the largest municipality in Sweden, has about 23000 inhabitants, covering $20500 \mathrm{~km}^{2}$, closely followed by Jokkmokk's $19000 \mathrm{~km}^{2}$.

35. Beland Lindahl et al., Konflikter om Gruvetablering - Lokalsamhällets aktörer och vägar till hållbarhet.

36. It is worth noting that although the Chief Mining Inspector makes a number of decisions on specific projects, these follow the overall legal framework decided on by the national Swedish government. Furthermore, these decisions can be appealed. Stakeholders, including the municipality, have the possible to appeal mining decisions to the Administrative Court, the Land and Environmental Court, and the Supreme Land and Environmental Court throughout the process (Swedish Environmental Code 1998:808). Yet, although a recognized national minority, and more importantly a recognized indigenous people, in Sweden the Sámi people have no special rights to influence the decision-making process specified in the legal framework. For mining developments in northern Sweden, the Sámi parliament is informed and consulted prior to decision-making, and sameby (the Sami reindeer herding communities) are usually considered one of many stakeholders because potential mines are located on reindeer grazing lands. This gives them the right to appeal decisions to the courts, a right that has also been exercised in several instances pertaining to the three cases analysed here.

37. SFS No. 1991:45, The Minerals Act, Stockholm: Swedish Parliamentary Record.

38. Natural Resources Canada, “10 Key Facts on Canada's Natural Resources”, Natural Resources Canada, 2016. http://www.nrcan.gc.ca/sites/www.nrcan.gc.ca/files/files/pdf/10_key_facts_nrcan_2016-access_e.pdf

39. Ken S. Coates, Greg Finnegan, Craig J. Hall and Kelly J. Lendsay, "Unearthing Human Resources" (Macdonald Laurier Institute, Ottawa, 2015), 1-40.

40. Northern Development Ministers Forum, "Saskatchewan: Key Industries," Northern Development Ministers Forum, 2017, http://www.focusnorth.ca/english/province/saskatchewan.php.

41. Coates et al., Unearthing Human Resources.

42. Ken S. Coates and Greg Poelzer, "The Next Northern Challenge: The Reality of the Provincial North," McDonald-Laurier Institute, 2014, http://www.usask.ca/icngd/publications/reports/Reports-Files/ MLI\%20Reality\%20of\%20the\%20Prov\%20Norths\%20Apr\%202014.pdf.

43. Saskatchewan Mineral Exploration and Government Advisory Committee, "Mineral Exploration Guidelines for Saskatchewan" (Ministry of the Environment, Government of Saskatchewan, 2012), http://publications.gov.sk.ca/documents/66/86271-mineralexploration.pdf.

44. Minister of the Environment, "Environmental Assessment in Saskatchewan" (Government of Saskatchewan, June 2014), http://www.environment.gov.sk.ca/EnvironmentalAssessmentProcess Guidelines.

45. Ministry of Environment, "Permits," Government of Saskatchewan, 2013, http://www.environment.gov. sk.ca/permits/.

46. Nuclear Safety Commission, "Fact Sheet: Uranium Mining and Milling: The Facts on a Well-Regulated Industry" (Government of Canada, July 2012), http:/nuclearsafety.gc.ca/eng/pdfs/Fact_Sheets/ Uranium-Mining-and-Milling-The-Facts-on-a-Well-Regulated-Industry-July-2012-eng.pdf.

47. Northern Engagement, "Mineral Surface Lease Agreements in Saskatchewan," Government of Saskatchewan, accessed March 20, 2017, https:/www.saskatchewan.ca/business/first-nations-metisand-northern-community-businesses/economic-development/mining-development-benefits-andagreements/mineral-surface-lease-agreements. 
48. Minister of the Environment, "Environmental Assessment in Saskatchewan"; Bram Noble, Introduction to Environmental Impact Assessment: A Guide to Principles and Practice, 3rd Edition (Don Mills, ON: Oxford University Press, 2015).

49. Noble, Introduction to Environmental Impact Assessment: A Guide to Principles and Practice.

50. Saskatchewan Mineral Exploration and Government Advisory Committee, "Mineral Exploration Guidelines For Saskatchewan"; Government of Saskatchewan, "The Surface Rights Acquisition and Compensation Act," \$ Chapter S-65 of The Revised Statutes of Saskatchewan, 1978 (1978), http://www. qp.gov.sk.ca/documents/English/Statutes/Statutes/S65.pdf.

51. In Canada, Band governments are the basic unit of government for First Nations bands, or "a body of Indians for whose collective use and benefit lands have been set apart or money is held by the Crown, or who have been declared to be a band for the purpose of the Indian Act" (Statistics Canada, 2016: 1). Under the Indian Act, the council of a band generally consists of one chief, and one councillor for every one hundred members of the band (Indian Act, 2017: 48). For more information, please read Statistics Canada, "Membership in a First Nations or Indian Band" (Statistics Canada), http://www12.statcan. gc.ca/nhs-enm/2011/ref/dict/pop070-eng.cfm; R.S.C., 1985, c. 1-5, The Indian Act, Canada: Minister of Justice.

52. Anna B. Costello and Jason W. Osborne, "Best Practices in Exploratory Factor Analysis: Four Recommendations for Getting the Most From Your Analysis," Practical Assessment, Research Ev Evaluation 10, No. 7 (2005): 1-9.; An Gie Yong and Sean Pearce, “A Beginner's Guide to Factor Analysis: Focusing on Exploratory Factor Analysis,” Tutorials in Quantitative Methods for Psychology 9, No. 2 (2013): 79-94.

53. Christine DiStefano, Min Zhu and Diana Mîndrilă, "Understand and Using Factor Scores: Considerations for the Applied Researcher," Practical Assessment, Research E Evaluation, Vol. 14, No. 20 (2009): 2 .

54. Vivien A. Schmidt, "Democracy and Legitimacy in the European Union Revisited: Input, Output and 'Throughput'," Political Studies 61, No. 1 (2013): 6.

55. For a discussion of Sami land rights, see: C. Allard, "Two Sides of the Coin" https://www.diva-portal. org/smash/get/diva2:999489/FULLTEXT01.pdf; Lawrence, R., \& Åhrén, M. (2017). Mining as colonisation: The need for restorative justice and restitution of traditional Sami lands. In L. Head, K. Saltzman, G. Setten, \& M. Stenseke (Eds.), Nature, temporality and environmental management: Scandinavian and Australian perspectives on peoples and landscapes (pp. 149-166). London; New York: Routledge. 